transmission of disease. When all else fails to prevent a blood ooze developing into an exsanguinating haemorrhage fibrin glue may save the patient.

H I ATRAH

West Midlands Regional Blood Transfusion

Service, Birmingham B15 2SG

1 Matras H. Fibrin sea: the state of the art. $f$ Oral Maxillofac Surg 1985;13:605-11.

2 Gibble JW, Ness PM. Fibrin glue: the perfect operative sealant? Transfusion 1990;30:741-7.

3 Kram HB, Nathan RC, Mackabee JR, Klien SR, Shoemaker WC. Clinical use of nonautologous fibrin glue. Am Surg 1988;54:570-3.

4 Spotniz WD, Dalton MS, Baker JW, Nolan SP. Reduction of perioperative hemorrhage by anterior mediastinal spray application of fibrin glue during cardiac operations. Ann Thorac Surg 1987;44:529-31.

5 McCarthy PM. Fibrin glue in cardiothoracic surgery. Transfusion Medicine Reviews 1993;7:173-9.

6 Ochsner MG, Maniscalco-Theberge ME, Champion HR. Fibrin glue as a hemostatic agent in hepatic and splenic trauma. I Trauma 1990;30:884-7.

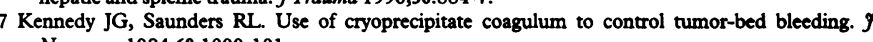
Neurosurg 1984;60:1099-101.

8 Lagoutte FM, Gauther L, Comte PRM. A fibrin sealant for perforated and preperforated comeal ulcers. Br F Ophthalmol 1989;73:757-61.

9 Silberstein LE, Williams LJ, Hughlett MA, Magee DA, Weisman RA. An autologous fibrinogenbased adhesive for use in otologic surgery. Transfusion 1988;28:319-21.
10 Feichtinger V, Barad D, Feinman M, Barg P. The use of two component fibrin sealant for embryo transfer. Fertil Steril 1990;54:733-4.

1 Sugiura $\mathrm{K}$, Nakatsuchi $Y$, Sugimoto $Y$. A new method for venous interposition grafts using fibrin glue. Microsurgery 1985;6:125-8.

12 Baudo F, deCataldo F, Landonio G, Muti G. Management of oral bleeding in haemophilic patients. Lancet 1988;ii: 1082 .

13 Thetter O. Fibrin adhesive and its application in thoracic surgery. Thorac Cardiovasc Surg 1981;29:290-2.

14 McCarthy PM, Trastek VF, Schaf HV. Esophagogastric anastomoses: the value of fibrin glue in preventing leakage. I Thorac Cardiovasc Surg 1987;93:234-9.

15 Schlag G, Redl H. Fibrin sealant in orthopedic surgery. Clin Orthop 1988;227:269-85.

6 Lilius P. Fibrin adhesive: its use in selected skin grafting. Practical note. Scand f Plast Reconstr Surg Hand Surg 1987;21:245-8.

17 Kram HB, Bansal M, Timberlake O, Shoemaker WC. Antibacterial effects of fibrin glueantibiotics mixtures. I Surg Res 1991;50:175-8.

18 de Virgilio C, Dubrow T, Sheppard BB. Fibrin glue inhibits intra-abdominal adhesion formation. Arch Surg 1990;125:1378-81.

19 Lindenberg S, Lauriston JG. Prevention of peritoneal adhesion formation by fibrin sealant. Ann Chir Gynaecol 1984;73:11-3.

20 Stricker RB, Lane PK, Leffert JD, Rodgers GM, Shuman MA, Corash L. Development of antithrombin antibodies following surgery in patients with prosthetic cardiac valves. Blood 1988;72:1375-80.

21 Lefrere J-J, Mariotti M, Thauvin M. B19 parvovirus DNA in solvent/detergent-treated antihaemophilia concentrates. Lancet 1994;343:211-2.

22 Evenson SA, Rollag H. Solvent/detergent-treated clotting factors and hepatitis A virus seroconversion. Lancet 1993;341:971-2.

23 Bumouf-Radosevich $M$, Burnof $T$, Huart J. Biochemical and physical properties of a solventdetergent-treated fibrin glue. Vox Sang 1990;58:77-84.

\title{
Starvation in hospital
}

\section{Nutrition is given too little attention by doctors, nurses, and managers}

The importance given to diet in medical treatment has had many ups and downs in the past 300 years. Nutritional science was rudimentary in the eighteenth century, ${ }^{1}$ but diet was probably a better option than the alternatives of bleeding or purging. At the beginning of the twentieth century many young men recruited for the Boer war were found to be seriously undernourished, so a school meals service was introduced. The golden period for nutrition was the 1930s, when most of the vitamins were discovered and shown to be therapeutically effective - in 1932, for example, the death rate among children with measles in a London fever hospital was reduced from $8 \cdot 7 \%$ to $3 \cdot 7 \%$ by a daily supplement of vitamin A from cod liver oil. ${ }^{2}$

The rationing system during the second world war was a spectacular success, and nutritionists concluded that there could not be any vitamins still to be discovered. Complacently, they decided that malnutrition was something that happened in the Third World and molecular biology became the priority for funding for research.

The neglect of nutrition in clinical medicine has now gone too far. The nutritional status of the population is getting worse, but the nature of the problem has changed. The prevalence of obesity (body mass index $>30$ ) in men and women rose from $6 \%$ and $8 \%$ respectively in 1980 to $8 \%$ and $12 \%$ in 1987 and to $13 \%$ and $15 \%$ in 1991 . As a consequence disease related to obesity has become ever more common. ${ }^{3}$ Obesity is not the only problem, however: on $\mathrm{p} 945 \mathrm{McWhirter}$ and Pennington report that in Britain (as in the United States) undernutrition is prevalent and largely unrecognised in hospital patients on admission and tends to get worse during their hospital stay. ${ }^{4}$ How is this possible in relatively affluent countries?

In part, the answer was supplied in a recent report from the King's Fund, which concluded that "doctors and nurses frequently fail to recognise undernourishment because they are not trained to look for it" and "every hospital should organise its nutritional services to link management, catering, and all the clinical disciplines involved." Sadly, progress is slow. A few medical colleges make a serious attempt to teach nutrition to their undergraduates, but most final year students know less about nutrition than about other branches of medicine. ${ }^{6}$ Without proper teaching, doctors-let alone the public -are misled by advertising material, which is often wildly inaccurate. ${ }^{7}$ The problem is not merely lack of learning; it is also lack of interest. Among the 200 cases of malnutrition reviewed by McWhirter and Pennington, fewer than half had any nutritional information documented in the case notes and few had had their weight and height recorded in the outpatient department. This is both important and, in my experience, typical.

No patient need become more malnourished in hospital. Modern methods of nutritional support of patients with special feeding problems are very effective. ${ }^{4} \mathrm{It}$ is administrative changes that have made it more difficult to ensure that ordinary patients get proper meals. Before the recent reforms if $\mathrm{Mr} \mathrm{A}$ had been fasted for blood tests in the morning and returned from radiology at $230 \mathrm{pm}$ having missed lunch the ward sister could provide him with scrambled egg on toast prepared in the ward kitchen. In most hospitals this is no longer possible: catering services are supplied on a tightly budgeted contract, and extra, informal meals require a special referral to the dietitian. High hygiene standards have the result that nurses are not allowed to prepare any cooked food in most ward kitchens, so $\mathrm{Mr}$ A will probably have to wait until his standard evening meal (having fasted for 24 hours). The same events may occur the next day. No wonder malnourished patients often lose weight in hospital.

Improving attitudes and practice will be a long haul. We need a generation of doctors, nurses, and managers who know and care about their patients' nutrition. Perhaps by the twenty first century the status of nutrition in clinical medicine will have climbed back to a more appropriate level.

JOHN GARROW

Rank professor of human nutrition

St Bartholomew's Hospital Medical College,

London EC1M 6BQ

1 Arbuthnot J. Essay concerning the nature of aliments. London: Tonson, 1731

2 Ellison JB. Intensive vitamin therapy in measles. BMF 1932;ii:708-11.

3 Garrow JS. Importance of obesity. BMF 1991;303:704-6.

$4 \mathrm{McWhirter} \mathrm{JP}$, Pennington $\mathrm{CR}$. Incidence and recognition of malnutrition in hospital. $B M f$ 1994;308:945-8.

5 Lennard-Jones JE. A positive approach to nutrition as treatment. London: King's Fund, 1992.

6 Parker D, Emmett PM, Heaton KW. Final year medical students' knowledge of practical nutrition. §R Soc Med 1992;85:338.

7 Philen RM, Ortiz DI, Auerbach SB, Falk H. Survey of advertising for nutritional supplements in health and body building magazines. $\Im A M A$ 1992;268:1008-11. 